\title{
GYNECOLOGICAL EXAMINATION EDUCATIONAL GUIDELINE FOR MATERNITY NURSES AND ITS REFLECTION ON WOMEN SATISFACTIONS
}

\section{Dr. Kamillia Rajab Abu Shabana ${ }^{1}$, Dr. Mahmoud Salah Mahmoud Rady ${ }^{2}, . D r$. Nagat Salah shalaby ${ }^{3}$ and Huda Abdulazim Elbnedari ${ }^{4}$}

Professor of Maternity and Gynecology Health Nursing, Faculty of Nursing, Ain Shams University ${ }^{1}$, Assistant professor of Obstetrics and gynecology medicine Faculty of Medicine, AlAzhar University ${ }^{2}$, Assistant professor of Maternity, Gynecology, and Obstetrics, Nursing Faculty of Nursing, Port Said University ${ }^{3}$, Master degree in Maternity, Gynecology \& Obstetrics Nursing Faculty of Nursing Port Said University ${ }^{4}$

\begin{abstract}
Background: The gynecological examination is an essential part and the most performed procedure in gynecological care, that the maternity nurses play a vital role during it. Aim: was to assess the effect of gynecological examination educational guidelines on maternity nurses' knowledge, practices and explore the women's satisfaction. Methodology: A quasi-experimental design was utilized for all nursemidwife working at Al-Azhar university hospital, and El Zarka Central Hospital in Damietta Governorate. A total of 40 nurses were recruited in the study and attended the educational program. A total of 120 women were recruited to explore their Satisfaction regarding gynecological examination care. Three tools were utilized for data collection first, structured interviewing questionnaire, observational checklist, and women's' satisfaction assessment tool. The Results revealed that: the nurses mean age was $30.7 \pm 3.10$. post-intervention most of maternity nurses $87.5 \%$ had correct knowledge about gynecological examinations, $85 \%$ of them had satisfactory care about gynecological examinations. Almost all studied women 95\% were satisfied with nursing care post-intervention Conclusion: The implemented educational guideline had a positive effect as it improves the nurses' knowledge and practice about gynecological examinations which inturn women were satisfied regarding care provided during gynecological examination. Recommendations: A training guideline regarding gynecological examination must be recommended for all nurses working at obstetric and gynecological units to improve the quality of care given to women. Also, further research to examine teaching vulvar self-examination and its implication for women at reproductive age.
\end{abstract}

Keywords: Educational guidelines, Gynecological examination, Nurses' knowledge, and practices, Women satisfactions . 


\section{INTRODUCTION}

The Gynecological examination has long been considered a fundamental component of a woman's health. A large number of women in the world will have a gynecological examination at some time in their lives, and some may undergo several examinations during their lifetime. It refers to the physical examination of female pelvic and breast organs. (Yanikkerem,2010 and Williams, et al.,2017and Elbana, 2019).In the Egyptian community gynecological morbidities are high especially in rural areas. A study conducted by (Yonis, Khattab, Zurayk, El mouelhy, 2018) suggests that pelvic examinations may cause pain, discomfort, fear, anxiety, or embarrassment in about $30 \%$ of women as a result of bad nursing care.

Although the importance of gynecological examinations, many ladies have negative experiences of gynecological examination as during the examination, women are in a particularly vulnerable situation and had a lack of data about the procedure. (Weisz, Escuredo, Soto \&Gutiérrez,2019; Siwe, et al.,2013; Royal College of Obstetricians and Gynecologists,2006). The procedure may trigger anxiety, embarrassment about undressing, worries about cleanliness, qualms about vaginal odor. Additionally, it may be experienced as very unpleasant and humiliating. fear of discovery of a pathological condition. As the gynecological examination is embarrassing and stressful for women, they expect that the nurse should provide full information to relieve anxiety and increase the sense of safety during the examination, as well as be a support person to the woman during the procedure (Yonis, et al. 2018).

Nurses play important roles in gynecological care, as she provides hands-on care to women which may range from total care (doing everything for someone) to partial care as helping a patient with illness prevention. The nurse maintains a patient's dignity while providing knowledgeable, skilled care. Also address psychosocial, developmental, cultural, and spiritual needs. which produces satisfied health care services. Because the improvement and adequacy of healthcare services are often measured by women's satisfaction and their relatives. (Karaca and Durna,2019; Murphy, McKenna, Abdelazim, Battiwalla, \& Stratton, 2019; Lambert, Daly \& Kunaviktikul, 2014).

Patient satisfaction is the most vital indicator of ideal nursing care and is considered an outcome of health care services. Patient satisfaction is a concrete 
criterion for evaluation of health care and the quality of nursing care Which requires powerful knowledgeable skillful nurses through applying many advanced teaching methods like an educational guideline. (Cooper, Polonec, \& Gelb, 2016).

Educational guidelines are important for health care especially within the gynecological examination as building knowledge and considered as a powerful tool for perfect performance improvement and to take care of the efficiency of gynecological care. Guideline assists maternity nurses and women, improves nurses' knowledge practices, and enhancing women's health which in turn decreases maternal mortality and morbidity. (Sajjadnia, et al.,2015, Mohamed, \& Mohamed,2019).

Gynecological examinations are major benefits to women so, health care professionals should aim to make this examination as comfortable and nonthreatening as possible, maintaining sensitivity and respect for the woman's dignity, which led to improving seeking care behavior, to decrease women mortality and morbidity, through improving nurses knowledge and practices According to the researcher available review of literature it was lacking in the study of the effect of educational guidelines about gynecological examinations on nurse's knowledge practices, and women's satisfaction in Damietta Governorate. So the current study was conducted to fill the gap of knowledge and add knowledge to the maternal newborn nursing specialty, the current study was conducted to inform nurses of the main issues surrounding intimate examinations and their role in providing optimum care.

\section{AIMS OF STUDY}

- Evaluate the effect of an educational guideline regarding gynecological examination on nurses' knowledge practices.

- Assess the women's satisfaction with nursing care post interventions.

\section{Research hypothesis:}

1- The educational guideline will upgrade the nurses' knowledge and practices about gynecological examinations.

2- The educational guideline will improve nurses' practices for women undergoing gynecological examinations.

\section{SUBJECTS AND METHOD}

\section{A-Research design}

A quasi-experimental design was conducted in this study. 


\section{B- Setting}

The study was conducted at two Hospitals in Damietta Governorate (Alazher University Hospital \& El Zarka Central Hospital).

\section{C - Sample}

The subjects in this study were two groups; The first one; all nurses who work in the previous mentions hospital were included in the sample total number was 40 . Meanwhile, the second group is a convenience sample of women who visited the previous mentions setting with the rate of three women with every nurse $(40 \times 3=120)$.

\section{TOOLS OF DATA COLLECTION:}

Data were collected by using the following tools:

TOOL I: A structure interviewing for nurses: It was developed by the researcher after reviewing relevant literature. It included two-part to collect the needed data about nurses' knowledge regarding gynecological examinations.

Part(1) :Personal data: as age, qualification ,occupation ,level of education ...etc.

Part(2) nurses role in gynecological examinations, and infection prevention measures during the examinations.

\section{Scoring system:-}

The response to each question ranged from $2=$ correct, $1=$ incomplete answer. And incorrect answer scored (0). The total scores were graded as $<60 \%$ uncorrected, $\geq 60$ corrected for each area of knowledge the score was summed up and converted into percent score.

Tool-II-Observational checklist (pre / post-test): was used to assess nurses' practices regarding gynecological examinations adapted from Qaseem et al; (2014): To assess the care provided to women at all phases of gynecological examination I- Preexamination: preparation of woman, Psychological preparation :(relief fear and anxiety...etc), Physical preparation: (explain the procedure, sterile examination area...etc), Environmental preparation: (adequate sterilization examination field...etc), Equipment, supplies preparation:(gloves, speculum, lubricant...etc) 2During the examination, Keep privacy. , Keep environment clean: (change bed linen, keep the bed dry, provide adequate light...etc), put women at suitable positions e.g lithotomy etc. Sterile of external genital area (perineal care...etc), Handle examination instruments. 3- After examination, Perineal care and apply the perineal 
pad., Keep woman at proper position., Return equipment, supplies., Discuss treatment as doctor order with woman.,Discuss follow-up examination visits with woman, Discuss time of return sexual relation with a woman. nurses educational role related to women self-examination,1- breast self-examination, 2-vulval self-examination.

Scoring system:- Care given for women during phases of gynecological examination was scored (1) if the response was done, (0) if it was not done. Total care (performance score) score, was determined as the following:- Unsatisfactory $<60 \%$, Satisfactory $\geq 60 \%$

TOOL III: Patient(women) Satisfaction Questionnaire with Nursing Care (PSNCQQ),: This tool was developed by Albashayreh et al. (2018), and modified by the researcher. It was used to evaluate women's satisfaction regarding nursing care including satisfaction regarding care during examination, doctor role, nurse role, and environment.

\section{women satisfaction scoring system:}

Each item was scored on a 3 -points Likert scale $(0=$ uncertain, $2=$ satisfied, $1=$ not satisfied). The total score ranged from 19-95. women consider not satisfied with the quality of nursing care if the total score was $<59$ and consider satisfied if total score $\geq 59$, as we collect uncertain and not satisfied to be not satisfied, as uncertain consider not satisfied

\section{Ethical Consideration:}

Official approval was taken from the Scientific Ethical Research Committee in the faculty of nursing in its session (4) 18/2/2019 at Port Said University to carry out the research. Moreover, an approval was taken from hospital directors to participate in the study after explaining the study aim, and approval was taken from each participant nurses and women after explanation of the study aim and details of the data collections process to be familiar with the importance of their participation, besides a brief and comprehensive explanation of the study was given to assured nurses and women that the information obtained was confidential and used only for purpose of the study.

The studied participants ( nurses and women ) were informed that their participation in the study was voluntary and they had the right to withdraw from the study at any time without rationalization, additionally, all data collected from the studied subjects were processed in total confidentiality, moreover, the process of data collection wasn't disturbed the harmony of the work of the above-mentioned setting. 


\section{I-procedure of work :}

The researcher reviews national and international web site Port said scientific journal of nursing, (PSSJN), Journal of Nursing and Health Science (IOSR-JNHS), American Journal of Nursing Research, (AJNR), International Journal of Caring Sciences, the University of Michigan, Center for vulvar diseases, Royal College of Nursing, Egyptian bank of knowledge, Google, An international library, Google Scholar and PubMed. And reviews the advanced related literature (Gynecological Examination CDHB Clinical Skills Unit, Improving the Pelvic Exam experience, Vaginal and Pelvic examination, Guidance for Nurses) different studies, using books, papers, journals, magazines, and theoretical knowledge of various aspects, then prepares the tools of data collections, finally conducts a pilot study to assess the content validity of tools used and practicability of the study.

\section{Tool validity}

All tools of data collections were developed and sent to five specialized university experts Prof in the field of study according to their comments, modifications were considered. Tools were submitted to three scholastic nursing specialists in the field of Maternity Nursing and Community Health Nursing to test content validity. Modifications were carried out according to the recommendations of the specialists.

\section{Reliability}

Tools validate for clarity, appropriateness, and completeness of the content. The reliability of the proposed tools was tested utilizing Cronbach's alpha. For the Preposttest, Cronbach's alpha of 0.81 showed a strong significant positive correlation between the items of the tool.

\section{Pilot Study}

After a review of the questionnaire by experts and their approval, a pilot study was carried out before starting the actual data collection. The purpose of the pilot study was to ascertain the clarity, and applicability of the study tools, and to identify the obstacles and problems that may be encountered during data collection. It also helped to estimate the time needed to fill in the questionnaire. It was done on $10 \%$ of the study participant (4 nurses and 12 women), and these were not included in the total sample of the research work to ensure the stability of the answers. Internal, 
external, and conclusion validity was done. Based on the results of the pilot study, modifications, clarifications, omissions, and rearrangement of some questions were done. to ensure the stability of the answers. Also, internal, external, and conclusion validity was done.

The study was implemented for ten-month, from the beginning of April month,(2018) to the end of January month,(2018). Implementation of the study was carried out at the gynecological unit affiliated at Alazher University Hospital and El Zarka Central Hospital. The researcher has visited the previously mentioned study setting three days per week, in the morning shift. Frist interview each nurse individual to obtain her oral consent to participate in the study. Each day three nurses were assessed pre interventions. The aim of the study was explained to each nurse to prompt her trust to participate in the. The nurses' knowledge and practices were assessed pre-intervention. Then educational guideline implementation phases were started. In the beginning, the studied nurses were divided into 8 groups each group consisted of 5 nurses. Each group was given the freedom to choose their optimal time for receiving the educational guideline. Then educational guideline was implemented through eight sessions.

The duration of each session was twenty minutes. Methods of teaching were lectures, small group discussions, bedside teaching, demonstration, and applications. Media used, lab top, gynecological examination equipment, handout, audiovisual material, and the real object. Three sessions were devoted to knowledge and five sessions were devoted to practices. At the end of the session, the designed booklet (handout) was provided immediately post interventions for nurses.

After completion of the intervention, the effect of the implementation of an educational guideline outcome was evaluated by using Tool I, II, and III. Immediately post interventions, nurses knowledge and practices were checked each day three nurses were observed while providing care of women during gynecological examinations. Each nurse was check while providing care to three women each day. Also, women satisfaction with the quality of nursing care was assessed post interventions.

\section{STATISTICAL DESIGN}

Collected data was arranged, tabulated, and analyzed according to the type of each data. Data entry and analysis were done using SPSS 16 (statistical packages for social science). Quality control was done at the stages of coding and data entry. 


\section{RESULT :}

The study Finding reveals that half of the studied nurses(50\%) were in the age group of (20-30)years old, with a Mean \pm SD of $30.7 \pm 3.10$. And three-quarters of them $(75 \%)$ had a technical institute in nursing. Besides near two-thirds of them $(62.5 \%)$ were living in urban areas and less than two-thirds of them (60\%) had more than 10 years of working experience. Also, No one of them had received any special training courses related to gynecological examination. Regarding studied women, the general characteristics of the studied women show that less than two-thirds of the studied women $(61,7 \%)$ were in the age group of (45-55)years old with a Mean \pm SD $44.03 \pm 6.87$. And less than half of them $(45,2 \%)$ had technical institute. Besides less than two-thirds of them (60\%) were living in urban areas.

Table (1): shows that there was a marked improvement in knowledge of the studied nurses about gynecological examination post-implementation of an educational guideline with a highly statistically significant difference at $(\mathrm{P}=<0.01)$ between pre and post-implementation of an educational guideline.

Table (2): presented that, there was a marked improvement in practical skills of the studied nurses about gynecological examinations post-implementation of an educational guideline with a highly statistically significant difference at $(\mathrm{P}=<0.01)$ between pre and post-implementation of an educational guideline at $\mathrm{p}<0.001$ ).

Figure (1): showed that less than half $(45 \%)$ of the studied nurses had incorrect knowledge about gynecological examinations at the pre-intervention. Meanwhile, the majority $(87.5 \%)$ of them had correct knowledge about gynecological examinations at post-intervention.

Table (3): indicated that there was a marked improvement in total practical skills of the studied nurses about gynecological examination post-implementation of an educational guideline with a highly statistically significant difference at $(\mathrm{P}=<0.01)$ between pre and post-implementation of an educational guideline evidence by (70\%) of the studied nurses had incorrect practical skills about total gynecological examinations at the pre-implementation of an educational guideline. While the majority $(85 \%)$ of them had correct practical skills about total gynecological examinations at post-interventions 
This figure (2): showed that $(40 \%$ and $25 \%)$ of the studied nurses had correct practical skills about breast self-examinations and self-vulvar examination at the pre-interventions. While ( $85 \%$ and $80 \%$ ) of them had correct practical skills about breast self-examinations and self-vulvar examination at post-implementation of an educational guideline

Table (4): presented that, all of the studied women were satisfied with the nurse's willingness and flexibility to meet their needs and quickly respond to them and the nurse's ability to calm them and make them feel comfortable during the examinations

Table (5): revealed that there was a highly statistically significant relation between total knowledge about the gynecological examination of the studied nurses and their residence and education \& also showed that there was a highly statistically significant relation between total practice about the gynecological examination of the studied nurses and their residence and education level at $(\mathrm{P}=<0.01)$.

Table (6): showed that there was a positive correlation between total knowledge, practices of the studied nurses about the gynecological examination, and women satisfaction at the post-intervention.

Table (1): Distribution of the studied nurses at pre and post-intervention of an educational guideline regarding their knowledge about preparation for gynecological examinations $(\mathrm{n}=40)$.

\begin{tabular}{|c|c|c|c|c|c|c|c|c|c|c|}
\hline \multirow[t]{4}{*}{ Items } & \multirow{2}{*}{\multicolumn{4}{|c|}{ Pre-intervention }} & \multirow{2}{*}{\multicolumn{4}{|c|}{ Post-intervention }} & \multicolumn{2}{|r|}{ T. test } \\
\hline & & & & & & & & & \multirow{3}{*}{$\mathbf{X 2}$} & \multirow[t]{3}{*}{ p-value } \\
\hline & \multicolumn{2}{|c|}{ Correct } & \multicolumn{2}{|c|}{ Incorrect } & \multicolumn{2}{|c|}{ Correct } & \multicolumn{2}{|c|}{ Incorrect } & & \\
\hline & $\mathbf{N}$ & $\%$ & $\mathbf{N}$ & $\%$ & $\mathbf{N}$ & $\%$ & $\mathbf{N}$ & $\%$ & & \\
\hline $\begin{array}{l}\text { Types of gynecological } \\
\text { examination }\end{array}$ & 21 & 52.5 & 19 & 47.5 & 34 & 85 & 6 & 15 & 16.52 & $.000 * *$ \\
\hline $\begin{array}{l}\text { Importance of gynecological } \\
\text { examination }\end{array}$ & 25 & 62.5 & 15 & 37.5 & 37 & 92.5 & 3 & 7.5 & 12.11 & $.000 * *$ \\
\hline $\begin{array}{l}\text { Disinfection solutions that are } \\
\text { used for examining area }\end{array}$ & 27 & 67.5 & 13 & 32.5 & 34 & 85 & 6 & 15 & 12.33 & $.000 * *$ \\
\hline $\begin{array}{l}\text { Types of speculum utilized in } \\
\text { examination }\end{array}$ & 18 & 45 & 22 & 55 & 36 & 90 & 4 & 10 & 17.67 & $.000 * *$ \\
\hline $\begin{array}{l}\text { Some simple equipment are } \\
\text { sterilized in the clinic during } \\
\text { examination }\end{array}$ & 20 & 50 & 20 & 50 & 33 & 82.5 & 7 & $\begin{array}{l}17 . \\
5\end{array}$ & 14.10 & $.000 * *$ \\
\hline Nurse role post examination & 19 & 47.5 & 21 & 52.5 & 38 & 95 & 2 & 5 & 18.31 & $.000^{* *}$ \\
\hline
\end{tabular}


Table (2): Distribution of the studied nurses at pre and post-intervention of an educational guideline regarding their practical skills about gynecological examinations $(n=40)$.

\begin{tabular}{|c|c|c|c|c|c|}
\hline \multirow[t]{2}{*}{ Items } & \multicolumn{2}{|c|}{ Pre-intervention } & \multicolumn{2}{|c|}{ Post-intervention } & \multirow{2}{*}{$\begin{array}{l}\text { T. test } \\
\text { X2 } \\
\text { p-value }\end{array}$} \\
\hline & $\begin{array}{l}\text { Correct } \\
\mathrm{N}(\%)\end{array}$ & $\begin{array}{l}\text { Incorrect } \\
\mathrm{N}(\%)\end{array}$ & $\begin{array}{l}\text { Correct } \\
\mathrm{N}(\%)\end{array}$ & $\begin{array}{l}\text { Incorrect } \\
\mathrm{N}(\%)\end{array}$ & \\
\hline \multicolumn{6}{|l|}{ Preparation for gynaecological E. } \\
\hline $\begin{array}{l}\text { Oriented patient about the meaning \& importance } \\
\text { of gynecological examinations }\end{array}$ & $\begin{array}{l}0 \\
(0.0)\end{array}$ & $\begin{array}{l}40 \\
(100)\end{array}$ & $\begin{array}{l}32 \\
(80)\end{array}$ & $\begin{array}{l}8 \\
8 \\
(20)\end{array}$ & $\begin{array}{l}12.97 \\
.000 * *\end{array}$ \\
\hline \multicolumn{6}{|l|}{ Infection prevention measures. } \\
\hline $\begin{array}{l}\text { Disinfectant patient skin with disinfectant } \\
\text { solution. }\end{array}$ & $\begin{array}{l}2 \\
(5)\end{array}$ & $\begin{array}{l}38 \\
(95)\end{array}$ & $\begin{array}{l}32 \\
(80)\end{array}$ & $\begin{array}{l}8 \\
(20)\end{array}$ & $\begin{array}{l}15.06 \\
.000 * *\end{array}$ \\
\hline \multicolumn{6}{|l|}{ Communication skills. } \\
\hline $\begin{array}{l}\text { The nurse introduces herself to patients, great } \\
\text { patients in a kindly manner, and offers the } \\
\text { woman a seat. }\end{array}$ & $\begin{array}{l}4 \\
(10)\end{array}$ & $\begin{array}{l}36 \\
(90)\end{array}$ & $\begin{array}{l}35 \\
(87.5)\end{array}$ & $\begin{array}{l}5 \\
(12.5)\end{array}$ & $\begin{array}{l}14.97 \\
.000^{* *}\end{array}$ \\
\hline Obtain history from the patient & $\begin{array}{l}0 \\
(0.0)\end{array}$ & $\begin{array}{l}40 \\
(100)\end{array}$ & $\begin{array}{l}30 \\
(75)\end{array}$ & $\begin{array}{l}10 \\
(25)\end{array}$ & $\begin{array}{l}16.01 \\
.000 * *\end{array}$ \\
\hline $\begin{array}{l}\text { Explain to the woman what is going to be done } \\
\text { and obtain her consent to perform the procedures. }\end{array}$ & $\begin{array}{l}4 \\
(10)\end{array}$ & $\begin{array}{l}36 \\
(90)\end{array}$ & $\begin{array}{l}32 \\
(80)\end{array}$ & $\begin{array}{l}8 \\
(20)\end{array}$ & $\begin{array}{l}14.20 \\
.000 * *\end{array}$ \\
\hline Explain the objective of each procedure & $\begin{array}{l}0 \\
(0.0)\end{array}$ & $\begin{array}{l}40 \\
(100)\end{array}$ & $\begin{array}{l}30 \\
(75)\end{array}$ & $\begin{array}{l}10 \\
(25)\end{array}$ & $\begin{array}{l}15.99 \\
.000 * *\end{array}$ \\
\hline $\begin{array}{l}\text { Provide continual emotional support and } \\
\text { reassurance, as possible. }\end{array}$ & $\begin{array}{l}4 \\
(10)\end{array}$ & $\begin{array}{l}36 \\
(90)\end{array}$ & $\begin{array}{l}35 \\
(87.5)\end{array}$ & $\begin{array}{l}5 \\
(12.5)\end{array}$ & $\begin{array}{l}17.21 \\
.000 * *\end{array}$ \\
\hline \multicolumn{6}{|l|}{ Environmental preparation } \\
\hline Check room ventilation & $\begin{array}{l}2 \\
(5)\end{array}$ & $\begin{array}{l}38 \\
(95)\end{array}$ & $\begin{array}{l}28 \\
(70)\end{array}$ & $\begin{array}{l}12 \\
(30)\end{array}$ & $\begin{array}{l}13.16 \\
.008 * *\end{array}$ \\
\hline Avoid air draft & $\begin{array}{l}2 \\
(5)\end{array}$ & $\begin{array}{l}38 \\
(95)\end{array}$ & $\begin{array}{l}28 \\
(70)\end{array}$ & $\begin{array}{l}12 \\
(30)\end{array}$ & $\begin{array}{l}13.10 \\
.000 * *\end{array}$ \\
\hline $\begin{array}{l}\text { Raise the examination table to the best level \& } \\
\text { good body mechanics }\end{array}$ & $\begin{array}{l}2 \\
(5)\end{array}$ & $\begin{array}{l}16 \\
(40)\end{array}$ & $\begin{array}{l}15 \\
(37.5)\end{array}$ & $\begin{array}{l}20 \\
(50)\end{array}$ & $\begin{array}{l}12.83 \\
.002 * *\end{array}$ \\
\hline \multicolumn{6}{|l|}{ Nurses role during gynecological examinations } \\
\hline Explain each procedure before its conduct & $\begin{array}{l}\underline{4} \\
\underline{(10)}\end{array}$ & $\begin{array}{l}\underline{36} \\
\underline{(90)}\end{array}$ & $\begin{array}{l}\underline{35} \\
\underline{(87.5)}\end{array}$ & $\begin{array}{l}\underline{5} \\
\underline{(12.5)}\end{array}$ & $\frac{14.95}{.000 * *}$ \\
\hline $\begin{array}{l}\text { Avoid cold instruments, Place speculum under } \\
\text { warm running water. }\end{array}$ & $\begin{array}{l}\underline{0} \\
\underline{(0.0)}\end{array}$ & $\begin{array}{l}\underline{40} \\
\underline{(100)}\end{array}$ & $\begin{array}{l}\underline{32} \\
\underline{(80)}\end{array}$ & $\begin{array}{l}\underline{8} \\
\underline{(20)}\end{array}$ & $\frac{14.90}{.000 * *}$ \\
\hline $\begin{array}{l}\text { Instruct patient to talk deep breathing during the } \\
\text { examination to relax her pelvic flora muscles }\end{array}$ & $\begin{array}{l}\underline{2} \\
\underline{(5)}\end{array}$ & $\begin{array}{l}\underline{38} \\
\underline{(95)}\end{array}$ & $\begin{array}{l}\underline{32} \\
\underline{(80)}\end{array}$ & $\begin{array}{l}\underline{8} \\
\underline{(20)}\end{array}$ & $\frac{15.12}{.000 * *}$ \\
\hline \multicolumn{6}{|l|}{ Post gynecological examinations nursing role } \\
\hline $\begin{array}{l}\text { Assist patient to get out of examining table } \\
\& w e a r \text { her clothes }\end{array}$ & $\begin{array}{l}10 \\
(25)\end{array}$ & $\begin{array}{l}30 \\
(75)\end{array}$ & $\begin{array}{l}35 \\
(87.5)\end{array}$ & $\begin{array}{l}5 \\
(12.5) \\
\end{array}$ & $\begin{array}{l}15.10 \\
.000^{* *}\end{array}$ \\
\hline $\begin{array}{l}\text { Give patient Instruction about Clinical, } \\
\text { discharge information \& Give patient written } \\
\text { instruction }\end{array}$ & $\begin{array}{l}2 \\
(5)\end{array}$ & $\begin{array}{l}38 \\
(95)\end{array}$ & $\begin{array}{l}28 \\
(70)\end{array}$ & $\begin{array}{l}12 \\
(30)\end{array}$ & $\begin{array}{l}13.87 \\
.006 * *\end{array}$ \\
\hline
\end{tabular}




\section{Total knowledge about gynecological examinations}

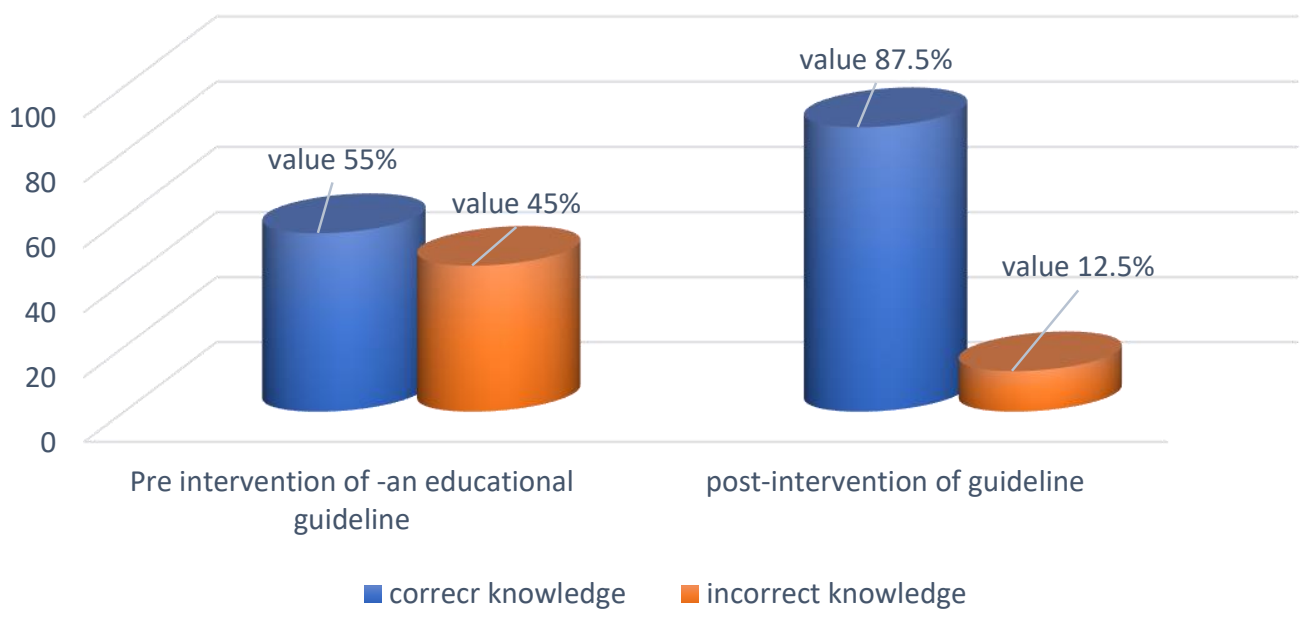

Figure (1): Distribution of the studied nurses at pre and post-intervention and their total knowledge about gynecological examinations $(n=40)$.

Table (3) Distribution of the studied nurses at pre and post-intervention of an educational guideline regarding their total practical skills about gynecological examination $(n=40)$.

\begin{tabular}{|c|c|c|c|c|c|c|}
\hline \multirow{3}{*}{$\begin{array}{l}\text { Level of total practical skills about, } \\
\text { gynecological examination }\end{array}$} & \multirow{2}{*}{\multicolumn{2}{|c|}{$\begin{array}{l}\text { Pre- } \\
\text { intervention }\end{array}$}} & \multirow{2}{*}{\multicolumn{2}{|c|}{$\begin{array}{l}\text { Post- } \\
\text { intervention }\end{array}$}} & \multicolumn{2}{|c|}{ T. test } \\
\hline & & & & & \multirow{2}{*}{$\mathrm{X} 2$} & \multirow{2}{*}{ p-value } \\
\hline & $\mathrm{N}$ & $\%$ & $\mathrm{~N}$ & $\%$ & & \\
\hline Satisfactory practical skills & 12 & 30 & 34 & 85 & & \\
\hline Un satisfactory practical skills & 28 & 70 & 6 & 15 & 22.36 & $.000 * *$ \\
\hline
\end{tabular}

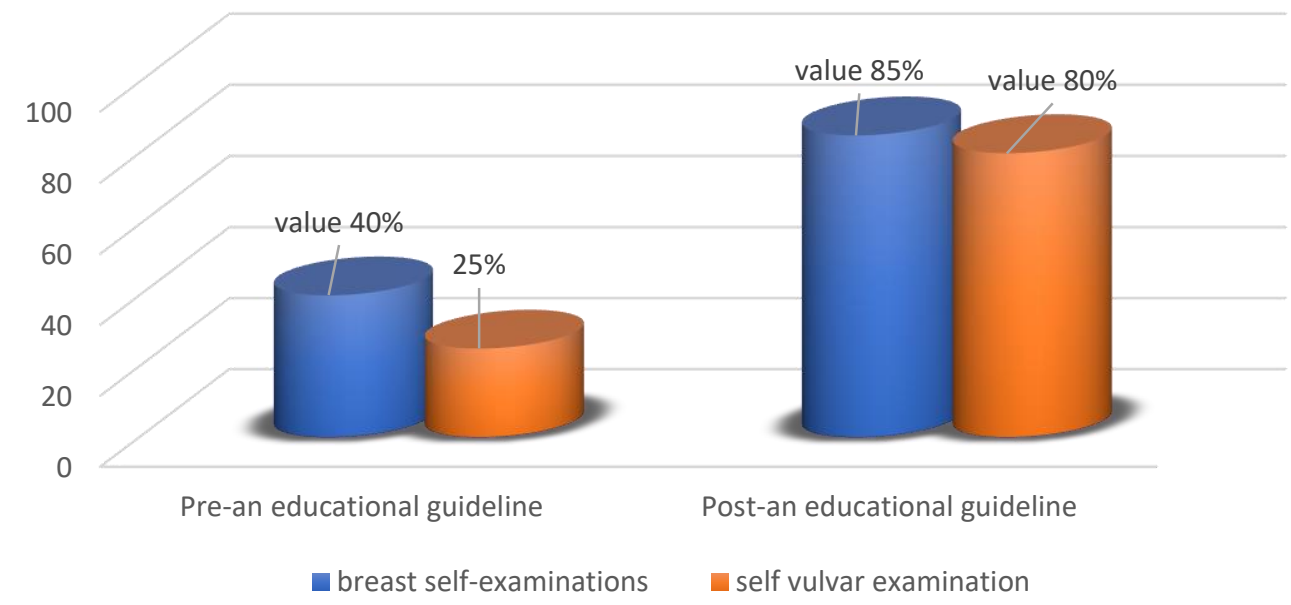

Figure (2): Distribution among studied nurses at pre and post-intervention of an educational guideline regarding their total educational practical roles about women breast self-examinations and self-vulvar examination $(n=40)$. 
Table (4): Distribution among studied women regarding their satisfaction with nursing care post interventions $(\mathrm{n}=120)$.

\begin{tabular}{|l|l|l|l|l|}
\hline \multirow{2}{*}{ Items } & \multicolumn{2}{|l|}{ Satisfied } & \multicolumn{2}{l|}{ Not satisfied } \\
\cline { 2 - 6 } & $\mathrm{N}$ & $\%$ & & \\
\hline The information provided to the women by the & & & & \\
nurse are: & & & & \\
\hline Clarity & 35 & 87.5 & 5 & 12.5 \\
\hline Inclusivity & 38 & 95 & 2 & 5 \\
\hline $\begin{array}{l}\text { Instructions: provided to the women by the } \\
\text { nurse: }\end{array}$ & & & & \\
\hline Before doing the examinations & 37 & 92.5 & 3 & 7.5 \\
\hline While conducting the examinations & 35 & 87.5 & 5 & 12.5 \\
\hline After performing the examinations & 38 & 95 & 2 & 5 \\
\hline $\begin{array}{l}\text { The nurse's method of answering women } \\
\text { inquiry in terms of: }\end{array}$ & & & & \\
\hline Listen attentively to Patient & 38 & 95 & 2 & 5 \\
\hline $\begin{array}{l}\text { The nurse's willingness and flexibility to meet } \\
\text { needs and quickly respond to women }\end{array}$ & 40 & 100 & 0 & 0.0 \\
\hline $\begin{array}{l}\text { The nurse's ability to calm the women and make } \\
\text { her feel comfortable }\end{array}$ & 40 & 100 & 0 & 0.0 \\
\hline The nurse considers women privacy & 40 & 100 & 0 & 0.0 \\
\hline $\begin{array}{l}\text { The quality of care and services women } \\
\text { received during her examination in general }\end{array}$ & 38 & 95 & 2 & 5 \\
\hline
\end{tabular}

Table (5): Relation between general characteristics of the studied nurses and their total knowledge \&practice about gynecological examination at post-intervention of an educational guideline $(n=40)$

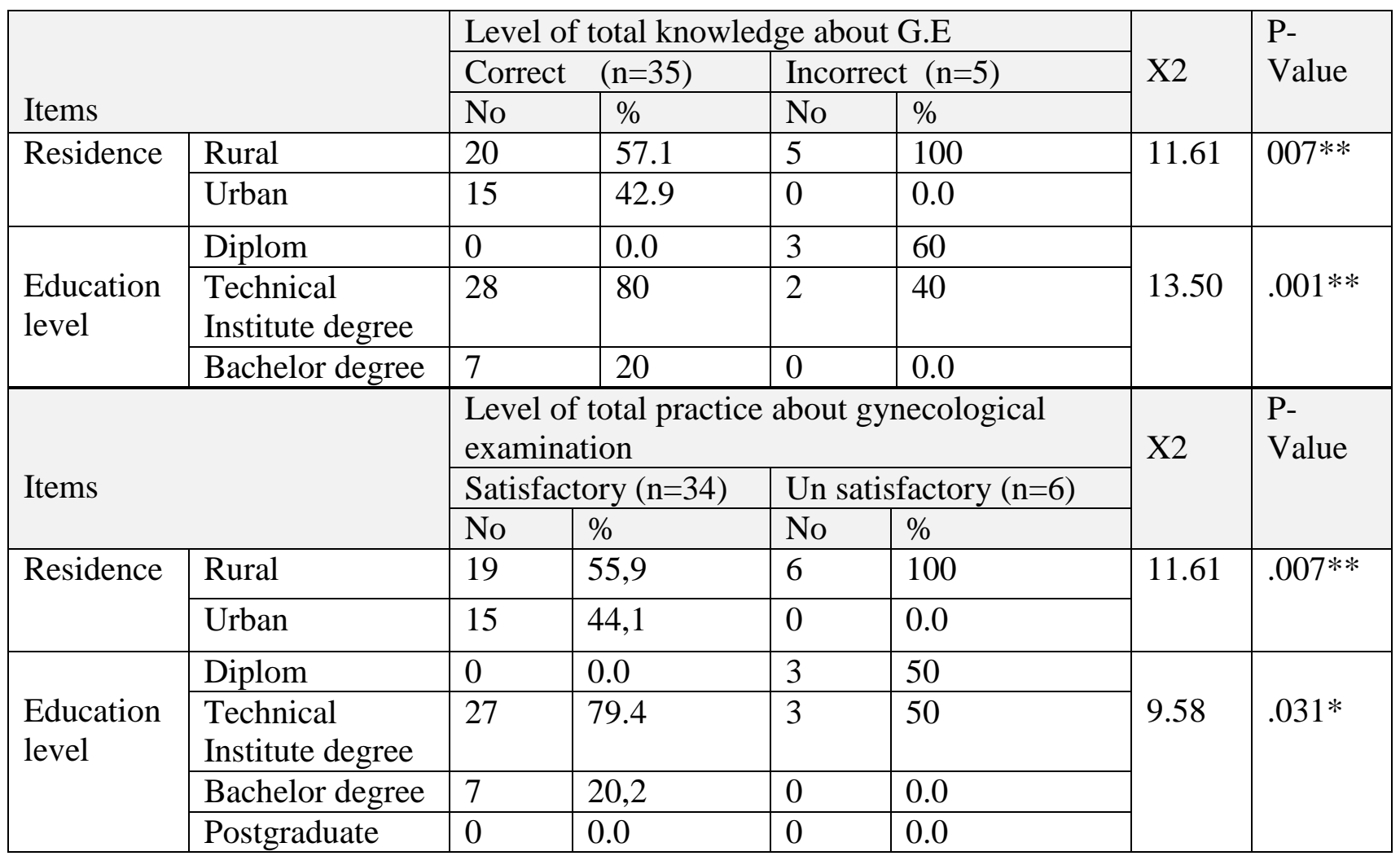

*significant at $\mathrm{p}<0.05$. **highly significant at $\mathrm{p}<0.01$. 
Table (6): Correlation between total knowledge of the studied s nurses about gynecological examination and their total practice and women satisfaction at post-intervention of an educational guideline.

\begin{tabular}{|l|l|l|l|l|}
\hline \multirow{2}{*}{ Item } & \multicolumn{2}{l|}{ Total knowledge } & \multicolumn{2}{l|}{ Total practice } \\
\cline { 3 - 6 } & $\mathrm{r}$ & P-value & $\mathrm{r}$ & P-value \\
\hline Total knowledge & & & .332 & $.000^{* *}$ \\
& & & & \\
\hline Total practice & .332 & $.000^{* *}$ & & \\
\hline Total satisfaction at post - guideline. & .412 & $.000^{* *}$ & .397 & $.000^{* *}$ \\
\hline
\end{tabular}

(*) Statistically significant at $\mathrm{p}<0.05$.

\section{DISCUSSION}

Gynecological examination is an essential part of any women's health care and must be accessible for all women to meet their health needs. Gynecological services must comply with the best available scientific evidence for the provision of highquality care. Nurses with improved knowledge and skills help to improve their ability to provide safe and effective quality care for women undergoing gynecological examination. Moreover, several studies supported that health care providers had an approval role in improving women's health. (Yonis, et al, 2018). The current study aimed to evaluate the effect of implementing an educational guideline regarding gynecological examination on nurses' knowledge, practices, and women satisfaction in the Damietta Government. This aim was significantly approved with the framework of the present study hyposis which was, nurses who receive the educational guideline will enhance their knowledge, practices about gynecological examinations, and women who receive gynecological examination after implementation of the guideline will be satisfied.

The present study reveals that no one of the studied nurses received any special training courses related to gynecological examination. This result agrees with a study conducted by, Belal, Gaheen, Mohamed (2016). Who found that all of the studied nurses didn't receive any training courses specialized in obstetrics. Also, the present study was in keeping with Sobeih and Nassr, (2015) as they reported that none of the nurses attended any training regarding gynecological examinations Within the same line, Kaushal, (2015) emphasizes the positive impact of an educational program on the knowledge and performance, hence, the healthcare organizations can engage in continuous training programs to regularly maintain and enhance the performance of the nurses. 
Moreover, Meddings et al. (2014) stated that changing practice isn't easy and may be costly, but it'll cost healthcare organizations more financially without adequately educating nurses about best practices. Also, Gordon, (2015) stated that Further training and education of nursing professionals can help to alleviate and limit the health complication which will be followed by improper gynecological examinations and increase the standard of care provided by healthcare providers nationally. Meanwhile, the attendance of such training courses had statistically significant associations with nurses' performance. In this respect, the theAmericanAssociationoffacultiesof of Nursing (AACN), encourages lifelong learning and offers incentives for nurses seeking to advance their education (AACN, 2014). It gives us a green line to the urgent need for training courses regarding gynecological examinations in the study setting.

Regarding Nurses' knowledge about gynecological examinations. Present study findings revealed an improvement of nurses' knowledge regarding gynecological examinations post interventions. There was a marked improvement in the proportion of correct answers to specific questions about the types and importance of gynecological examinations. Also regarding nurse's preparation for gynecological examinations, the present study presented that, most of the studied nurses had correct knowledge regarding disinfection solutions that are used for examining the area, types of speculum utilized in the examination, disinfection solution used to sterilize gynecological instruments, and nurse role post-examination post interventions. This all agree with, Elbana,(2019) in Benha, in his findings illustrated that there was significant improvement of nurses' knowledge postintervention in the proportion of correct answers to specific questions about, purpose, types of GE, methods of GE, Instrument, disinfectant solutions and supplies for GE.

These results were supported by Olumide, Oluwatosin, John, and Francis (2014). in Nigeria. who showed in his study that the mean knowledge and perception scores were also improved post-intervention. Also, that was agreed with the Royal college of nursing ( 2019): Recommendation for caring out genital examinations should be followed whenever possible. The room should be stocked in advance with the necessary supplies to allow the examination to proceed as quickly as possible. A range of speculum sizes should be on hand to choose from, to make the examination as physically comfortable as possible. 
As regards nurses' knowledge about infection prevention measures related to gynecological examinations and equipment's disinfectant measure throughout the educational guideline intervention. The present study findings revealed that the improvement of nurses' knowledge regarding infection prevention measures and equipment's disinfectant measure post interventions. These results agree with Arafat1, Mahdy, El-Kashif,(2018) who showed that a large percent of studied nurses had poor knowledge regarding nosocomial infection control before induction of the guidelines. This also agrees with the study conducted by Sarani,Balouchi, Masinaeinezhad, \& Ebrahimitabs (2015). They revealed that more than two-thirds of the participants had poor knowledge related to general infection prevention and gynecological equipments disinfectant measures pre interventions. Also, another study mentioned that only less than one-third of nurses had good knowledge of infection control principles and equipment's disinfectant measures post-intervention (Tirivanhu, Ancia, \& Petronella, 2014).

The current study highlights that there was a marked improvement in total knowledge of the studied nurses about nursing role pre, during, and postgynecological examinations post-intervention as, less than half of the studied sample had incorrect knowledge about gynecological examinations at the pre-interventions. While the majority of them had correct knowledge about gynecological examinations post-intervention. This was agreed with Elbana,(2019) in Benha, who revealed that there was a highly statistically significant difference in studied nurses' general knowledge related to their role of gynecological examination between the pre and post-intervention. As more than half of studied maternity nurses' had a poor level of knowledge regarding all knowledge items concerning gynecological examination at the pre-intervention phase. These results also agree with Mahrous, (2018). Who stated that about three-quarters of the studied nurse had poor knowledge regarding gynecological examinations per-interventions. These findings may be due to a lack of implementing educational guidelines about gynecological examination in the studied setting. This high lightened that the educational training was highly indicated.

As regard nurses' practical skills in gynecological examinations, the present study presented that, there was a marked improvement in the practice skills of the studied nurses about gynecological examinations care post-interventions with a highly statistically significant difference between pre and post-interventions. Regarding preparation for gynecological examinations, infection prevention 
measures, communication skills, environmental preparation, and nurses role during, post gynecological examinations. This result supports the importance of educational intervention for maternity nurses regarding nurses skills of gynecological examination care. Also, these results agreed with El- Shafey, (2017) who mentioned that majority of the studied nurse's not explained the procedure to women and did not ask to empty the bladder pre-interventions the possible explanation may be due to the nurse not received any special courses regarding gynecological examination in the clinical setting.

In this respect, Ali and Taha, (2014): suggested that a multipronged approach that includes structured educational in-services, informal discussions with supervisors, and identifying effective linkages such as medical directors, infection control professionals, long-term care organizations, and nursing mentors may be required to promote the use of recommended infection prevention practices. Besides Moustafa et al. (2015), also added that nurses have been taught the principles of infection control; however, they may not be able to interpret and implement these principles into practice. Therefore, translation of the prevention guideline into clinical practice is required.

There was a marked change in overall practices in the light of the present study as near two-thirty of the studied nurses had incorrect practices about total gynecological examinations at the pre-intervention phase. But post-intervention the percent of nurses who had incorrect practices decrease to reaches to less than one quarter. While most of them had correct practical skills about gynecological examinations at postinterventions. Within the same scenario Abd-Elhamid, El-khashab, Saleh, (2016). They found that there was a highly important statistical increase in gynecological exams in the overall standard of practice of nurses. This outcome was also consistent with El Ghatey et al (2013), who confirmed that there were highly statistically relevant variations between the pre and post-intervention practices of nurses.

Besides that, this result agrees with Ali and Taha, (2014): who claimed that after the intervention, the advancement in nursing practices was also noticeable because their practices were even worse compared to awareness before the guideline. And in the pre-program process, none of them had sufficient practice, but the required practice persisted in the follow-up. This might be associated with the effect of knowledge on practices, like an increased level of information, the amount of selfconfidence also increases, and therefore the individual can practice more accurately. 
About the total practice of studied nurses concerning educational role about women breast self -examination. The present study shows that there is a, statistically significant difference in the study nurses' total practices about BE as the level of practice increased post interventions. These results are consistent with Ahmed ;( 2020). Who showed that during the preprogram, three-quarters of the study participants have correct knowledge about BE, and most of the participants know that it helps early detection of breast cancer (BC), immediately after the program implementation. In the same line, a study by Ahmed et al. (2017), Revealed that more than two-fifths of study participants practices about BSE improved post interventions, also agrees with research conducted by Anakwenze et al. (2015) disputed the findings of the current study. These findings were also consistent with Ramadan and Mohamed (2015), who revealed that after the induction of the program, there was a substantial increase in the level of women's BSE practice.

Also agree with a study performed by Moussa and Shalaby (2014), who stated that the educational program had a significant effect on increasing the level of practice on BSE from no one to almost all of the participants performing BSE correctly. And according to Moussa and Shalaby, the main reason for not practicing BSE before the program was that they did not know the right way to perform it. Furthermore, a study carried out by Moustafa et al. (2015), at Zigzag City, found that there was a substantial improvement in the level of practices of the participants' post interventions.

It is obvious from the present study that nurses' practices about educational roles regarding women self-vulvar examinations, where three-quarters of the studied nurses had incorrect practical skills about nurse's educational role about women selfvulvar examination pre-intervention. While more than three-quarters of them had correct practical skills post-intervention. It is worth noting that all of (100\%) the studied nurses had correct and complete knowledge about women self-vulvar examinations post interventions, but more than three-quarters of them only provide women health teaching about it, because, they know that I'm watching them while practicing, meanwhile less than one-quarter of them refuse to do that because of they are very embarrassing to say steps of self-vulvar examination to the women which may be due to their cultures' background. There's no study illustrated nurses' educational role about women self-vulvar examination but, there are some articles 
and books (Vulvodynia: A Self-Help Guide) that discuss vulvar self-examination as a procedure.

Although according to Mercy, et al. (2019). Invasive cervical cancer is preventable, yet affects 500,000 women worldwide each year, and over half these women die. and barriers to cervical cancer screening include lack of awareness of cervical cancer and the cervix, fear of the speculum, and lack of women-centric technologies. like Vulvar self-examination (VSE) which was an essential examination that all women should perform monthly, as it enables potential patients to discover vulvar cancer in an early stage. In a study conducted by Choi, and Park,;(2018),. Reveled that young women's willingness to conduct VSE. was higher if the perceived benefit and the individual health motivation were higher. However, it was lower if the perceived barriers were higher. For that, systematic strategies should be included in VSE education programs to increase perceived benefits of, and health motivation for conducting VSE while reducing the perceived barriers to VSE.

Additionally, the findings of the current analysis have shown that (less than half and one quarter) (40\% and 25\%) respectively of the studied nurses had correct practical skills about educational practical role about women breast self-examinations and women self-vulvar examination at the pre-intervention. While most $(85 \%$ and $80 \%$ ) of them respectively had correct practical skills about breast examinations and vulvar examination at post-interventions. The possible explanation of these results may be due to differences in culture as breast self-examination had occupied the mind of many researchers contradict self-vulvar examination. Also, we can realize that defects in social media (Bahia foundation) as breast self-examination occupied the whole view, but self- vulvar examination almost no one or a very few nurses and women know about it although the high prevalence of vulvar cancer. Mercy, et al ; 2019).

The study highlights that the majority of studied women were satisfied with nursing care during gynecological examination post-intervention. As regarding the nurse's willingness and adaptability to satisfy their needs and quickly answer them and also the nurse's ability to calm them and make them feel comfortable during the examinations. Also, most of them were satisfied with the standard of procedures provided by the nurse, and therefore the quality of care and services they received during examination generally. This finding disagrees with a study conducted at Benha university hospital by Nashwa, Nadia, Soad, Aziza (2018). Which 
concluded that over half the studied women had unsatisfactory care regarding the gynecological examination.

The current research showed that there was a highly statistically relevant association between total knowledge, total practices about the gynecological examination of the studied nurses, and their residence, education level which disagreement with the research of Kavitha et al. ( 2014); who discovered that there was no substantial connexion between the knowledge and practices of the studied nurse and their residents, level of education. Although the findings of the current study were consistent with the results of Pehlivan and Kaushar's(2013); in previous studies. they conclude that rural students have a higher level of experience and practice than urban ones. Again, Nassar (2015); shows that the level of education was strong predictors to test nurse knowledge and practice Besides, the research of Yahya et al. (2017) found that there is a positive connexion between the score of knowledge and practice and the studied nurse's characteristic

Regarding the correlation between, total knowledge of the studied nurses, and women satisfaction at post interventions of an educational guideline. The current study showed there was a highly positive association between them that indicated improves knowledge and subsequently enhances women's satisfaction with nursing care. This was accepted true by Maqsood, et al in(2020). Who revealed that better service quality led to patient satisfaction While these results disagree with the study of Eldeeb and Eldosoky (2016). Who showed a non-significant correlation between nurses knowledge and patient satisfaction among nurse interns regarding gynecological examinations, It could be explained by patient satisfaction is greatly affected by knowledgeable nurses.

As regarding the correlation between total knowledge and total practice of the studied nurses at post interventions. The present study showed that a very positive relationship existed between them. The results agree with Elbana (2019) in Benha, who demonstrated that there was a strong positive relationship between them that showed that improving nurses knowledge subsequently improves practice. Ramadan, SharKawy, (2019) also agreed with these findings. Who disclosed that after the execution of the program, there is a strong connexion between awareness and practice scores of study participants. In the same line, these findings the report by Nassar (2015). Who claimed that the training program implementations were more successful in improving the awareness of study participants, contributing to progress 
in their practice. Also, the study was carried out by Mohamed (2018). Who claimed a positive correlation between participants 'knowledge and practice post-interventions.

While these results in disagreement with the study of Eldeeb and Eldosoky (2016). Who showed a non-significant correlation between knowledge and skills scores among nurse interns regarding gynecological examinations. In general, bad practices occurred before the introduction of educational guidelines. This is explained by a lack of knowledge about gynecological examinations in the pre interventions period. Lack of clinical education, skill expertise, and practice style traits have all been documented as influencing nurses' use of evidence-based practice. Post interventions, there was a significant statistical improvement in practices. This could be justified by improving knowledge post-intervention led improvement in practics. This finding coincides with many studies that supported the positive correlation between knowledge and practices.

\section{CONCLUSION:}

The implemented educational guideline had a positive effect as it improves the nurses' knowledge and practice about gynecological examinations which inturn women were satisfied regarding care provided during gynecological examination.

\section{RECOMMENDATIONS:}

A training guideline regarding gynecological examination must be recommended for all nurses working at obstetric and gynecological units to improve the quality of care given to women. Also, further research to examine teaching vulvar self-examination and its implication for women at reproductive age.

\section{REFERENCES}

Abd-El Hamid, A., El-khashab,M. , Saleh, N., (2016). Impact of Training Education Program on Improving of Nurses Performance Regarding Infection Control in Endoscopy UnitAfro-Egypt $J$ Infect Endem Dis 6(1): 16-28 http://mis.zu.edu.eg/ajied/home.aspx

Ahmed A., Abd EL, Hamed A., Azzam H.,(2017). Effect of breast selfexamination training program on knowledge and practice of adolescent girls Int J Res Appl Nat Soc Sci 5:35-48, [Downloaded free from http://www.enj.eg.net on Monday, June 22, 2020, IP: 102.184.251.186].

Ahmed, S.(2020). The effect of health promotion program on female breast self-examination knowledge and practice, Canal University, Suez Canal, Egypt., Tel: 
+201097338157, e-mail: shabd.gimsct@gmail.com, Received 30 September 2018, Accepted 29 October 2018/Egyptian Nursing Journal 2019, 16:25-35 [Downloaded free from http://www.enj.eg.net on Monday, June 22, 2020, IP: 102.184.251.186]

Albashayreh, A., Al-Rawajfah O., Al-Awaisi H., Karkada S., \& Alsabei S. (2018). Psychometric properties of an Arabic version of the patient satisfaction with nursing care quality questionnaire. The Journal of Nursing Research, p.p, 1-9.

Ali H., Taha M.,(2014). Effect of Infection Control Training Program on Nurse's Performance and Microbial Results on GIT Endoscopes. Advances in Life Science and Technology 2014;27:6-16.

American Association of Colleges of Nursing (AACN) (2014): The Impact of Education on Nursing Practice. Available at http://www.aacn.nche.edu/mediarelations/fact-sheets/impact-of-education.internet accessed in November 2014.

Anakwenze C., Coronado-Interis E., Aung M., Jolly P., (2015). A theorybased intervention to improve breast cancer awareness and screening in Jamaica Prev Sci 16:578-585

Belal, G. Gaheen, M. Mohamed, F. (2016): The educational needs among obstetrical and gynecological nurses in El-Gharbia Governorate Journal of Nursing Education and Practice; ISSN 1925-4040 E-ISSN 1925-4059 Received: October 5, 2016, Accepted: November 29, 2016 Online Published: December 21, 2015, DOI: 10.5430/jnep.v6n4p84 URL:http://dx.doi.org/10.5430/jnep.v6n4p84.

Choi, J. and Park, M.;(2018). Factors predicting young women's willingness to conduct vulvar self-examinations in Korea, December Health Care For Women International 40(2):1-12, DOI: 10.1080/07399332.2018.1531003

Cooper C., Polonec L., \& Gelb C.., (2016). Women's knowledge and awareness of gynecologic cancer: a multisite qualitative study in the United States. $J$ Women's Health (Larchmt); 20 (4): p.p. 517-24.

El Ghatey A, Mahrous F, Gendy J.,(2013). Impact of Universal Infection Control Intervention Program for Nurses at Asser Hospital Medical-Surgical Nursing Department, Faculty of Nursing, King Khalid University, Abha, Saudi Arabia. Journal of American Science 2013; 9(12) 940:948 http://www.jofamericanscience.org.

Elbana, H., (2019).Maternity nurses' performance regarding gynecological examination: Educational intervention, IOSR Journal of Nursing and Health Science (IOSR-JNHS)e-ISSN: 2320-1959.p- ISSN: 2320-1940 Volume 7, Issue 6 Ver. IX. (Nov.-Dec.2018), PP 66-77 www.iosrjournals.org

Eldeeb G ., and Eldosoky E .,(2016). Relationship between Effectiveness of Time Management and Stress levels among Nursing Students. Journal of Nursing and Health Science, 5, (2), PP 95-100 . 
Gordon P.,( 2015).The Effects of Nursing Education on Decreasing Catheter-Associated Urinary Tract Infection Rates, Doctor of Nursing Practice (DNP), College of Health Sciences, Walden University, P.1-18.

Karaca A., Durna Z.(2019). Patient satisfaction with the quality of nursing care patient satisfaction with nursing care. Nursing Open.;00:1-11. https://doi.org/10.1002/nop2.237

Kaushal G., (2015). Impact of Training on Knowledge, Attitude and Practices Scores of ICU Nurses regarding Standard Precautions of Infection Control in a Super Speciality Hospital of Delhi, Indian Journal of Research, Volume: 4 | Issue: 8.P.282-

Kavitha P., Tesfay A., Prasath R., Habtegiorgis L., Girmay S., and Sereke Y. (2014): To assess the level of knowledge of nurse interns on emergency obstetric management at orotta national referral maternity hospital, Int. J. of Allied Med. Sci. and Clin. Research Vol-2(4) pp. 287-293.

Lambert V., Daly J., Kunaviktikul W., (2014).Nursing Education on Women's Health Care in Australia, Japan, South Korea, and Thailand. Journal of Transcultural Nursing. 15(1):p.p 44-53. Mid: 14768415 available at http://dx.doi.org/10.1177/104365960.

Mahrous, M.,(2018). Knowledge, practice, and attitude regarding gynecological examination among maternity nurses in Benha university hospital, master thesis pp.102-105.

. Arafat, M., Mahdy, A., El-Kashif, M., (2018).The Effect of EvidenceBased Guidelines on Nurses, Performance in Respect to Nosocomial Infection at Medical-Surgical and Obstetrician Departments, American Journal of Nursing Research, 2018, Vol. 6, No. 6, 507-514 Available online at http://pubs.sciepub.com/ajnr/6/6/19 OScience and Education Publishing DOI:10.12691/ajnr-6-6-19

Maqsood, M. kousar, H. jabeen, A. Waqas, A. Gillani, S.;(2020). Effects of hospital service quality on patients satisfaction and behavioral intention of doctors and nurses, Saudi Journal of Medical and Pharmaceutical Sciences ISSN 2413-4929 (Print) Scholars Middle, East, Publishers, ISSN,2413-4910 (Online) Dubai, United Arab Emirates, Website: http://scholarsmepub.com/

Meddings J., Rogers, M., Krein, S., Fakih, M., Olmsted, R.., \& Saint, S. (2014). Reducing unnecessary urinary catheter use and other strategies to prevent catheter-associated urinary tract infection: an integrative review. BMJ Quality \& Safety, 23(4), 277-28289.

Mercy N. Asiedu MScJúlia S. Agudogo Mary Elizabeth Dotson, Marlee S. Krieger, John W. Schmitt MD Megan Huchko MD, Gita Suneja, Rae Jean 
Proeschold-Bell, Jennifer S. Smith, Deborah Jenson, Wesley Hogan, Nirmala Ramanujam, ;(2019). A Novel, Versatile Speculum-free Callascope for Clinical Examination and Self-Visualization of the Cervix,bioRxiv preprint DOI: https://doi.org/10.1101/618348. It is made available under a CC-BY-NC-ND 4.0 International license.

Mohamed A., (2018) .designing a training program for improvement of nurse interns' knowledge and practice regarding occupational hazards. unpublish doctorate thesis, faculty of nursing, zagazig university.

Mohamed, S.,\& Mohamed, A.,(2019): Maternity and Gynecological Nursing. pp. 660-665 and 827-848. ISBN 978-0133876406.

Moussa M., Shalaby N., (2014). Effect of breast self-examination education program on knowledge, attitude, and practice of nursing students. Int J Res, Studies Biosci 2:40-49

Moustafa D., Abd-allah E., Taha N., (2015). Effect of a breast-self examination(BSE) educational intervention among female university students. Am J, Nurs Sci 4:159-165

Murphy, J., McKenna, M., Abdelazim, S., Battiwalla, M., \& Stratton, P. (2019). A Practical Guide to Gynecologic and Reproductive Health in Women Undergoing Hematopoietic Stem Cell Transplant. Biology of Blood and Marrow Transplantation.

Nashwa M., Nadia M., Soad A.., Aziza M.,(2018).Assessment of Care Given to Woman UndergoingGynecological Examination Egyptian Journal of Health Care, EJHC Vol.9 No.1

Nassar R., (2015): Designing training program: A Mean for Prevention of Occupational hazards that Face Nurse interns, faculty of Nursing Menoufia university.

Pehlivan, Q., \& Kaushar, G., (2013). The Effect of the Time Management Skills of Students Taking a Financial Accounting Course on their Course Grades and Grade Point Averages. International Journal of Business and Social Science Vol. 4 No. 5; May 20-34.

Qaseem A., Humphrey L.., Harris R., Starkey M., and Denberg T., (2014). Screening pelvic examination in adult women: a clinical practice guideline from the American College of Physicians. Clinical Guidelines Committee of the American College of Physicians. Ann Intern Med. 161:67-72.

Ramadan, E. Abd El Hady, R. SharKawy, A. (2019).Effect of Training Program on Nurse Intern's Knowledge and Practice Regarding Obstetric and Gynecological Skills at Benha University Hospital, American Journal of Nursing 
Research, Vol. 7, No. 5, 889-898, Available online at http://pubs.sciepub.com/ajnr/7/5/22 Published by Science and Education Publishing, DOI:10.12691/and-7-5-22.

Olumide A Abiodun, Oluwatosin O Olu-Abiodun, John O Sotunsa, and Francis A Oluwole(2014): Impact of health education intervention on knowledge and perception of cervical cancer and cervical screening uptake among adult women in rural communities in Nigeria BMC Public Health. 2014; 14: 814.DOI: 10.1186/1471-2458-14-814.

Royal College of Obstetricians and Gynecologists (2006); Vaginal and pelvic exam (guidance for nurses and midwives), Published by the Royal College of Nursing, 20 Cavendish Square, London, W1G 0RN,3available at:www.rcog.org.uk.

Sajjadnia Z., Sadeghi A., Kavosi Z., (2015). Factors affecting the nurses' motivation for participating in the in-service training courses: A case study. J Health Man \& Info. 2(1): 21-26. http://dx.doi.org/10.3855/jidc.526,Summary Report. Available online at, http://www.hpvcentre.net/statistics/reports/EGY.pdf.

Sarani, H., Balouchi, A., Masinaeinezhad, N., \& Ebrahimitabs (2015). Knowledge, Attitude and Practices of Nurses about Standard Precaution for Hospital Acquired Stellenbosch University https://scholar.sun.ac.za Infection in Teaching Hospitals Affiliated to Zabol University of Medical Science. Global Journal of health science.

El- Shafey, N., (2017): Assessment of care given to women undergoing gynecological examination Master thesis, Faculty of Nursing, Benha university .pp 4,61-65.

Tirivanhu, C., Ancia, M. \& Petronella, S. (2014). Barriers to infection prevention and control practice among nurses at Bindura provincial hospital, Zimbabwe. Journal of nursing and health science 1(3): 69-73.

Siwe, K., Berterö, C., \& Wijma, B. (2013). Gynecological patients learning to perform the pelvic examination: a win-win concept. Sexual \& Reproductive Healthcare, 4(2), 73-77.

Sobeih H. and Nasr M. (2015): Indwelling Urinary Catheter Management: Effect of an Interactive Workshop on Nurses' practice and Perception. New York Science Journal 2015;8(5).PP.117-124.

Weisz, L., Escuredo, I., Soto, J., \& Gutiérrez, J. , (2019). Toxic epidermal necrolysis (TEN): Acute complications and long-term sequelae management in a multidisciplinary follow-up. Journal of Plastic, Reconstructive \& Aesthetic Surgery. , 4(2), 73-77. 
Williams, P., et al. Gray's,(2017): Anatomy, 38th ed. New York: Churchill Livingstone, pp. 1861-1877.

Yahya W ., Alamodi1 L ., Mohammed A ., Shibah A ., Jabri1S ., Albosruor Z ., (2017): The Effect of Time Management on Academic Performance among Students of Jazan University. the Egyptian Journal of Hospital Medicine, 69 (8), PP: 3042-3049.

Yanikkerem, E., Özdemir M., and Gülten Karadeniz, PhDP, (2010). Women's attitudes and expectations regarding gynecological examination; 25(5): 500-508. doi:10.1016/j.midw.2010.08.006.

Yonis, N., Khttab H., Zurayk H., El mouelhyM., (2018). A Community Study of Gynecological and Related Morbidities in Rural Egypt, The Journal of Nursing Research 24(3):175-86.

\section{الأرشادات التعليمية للفحوصات النسائية لتمريض النساء وانعكاسها علي رضا السيدات}

\section{الخلاصة}

تعتبر الفحوصات النسائية الجز اء الاساسي و الاكثر شيو عا الرعاية المقدمة للسيدات في العالم حيث تهدف هذه الدراسة الى تقييم تأثير تنفيذ كتيب ارشادي تعليمي عن الفحوصات النسائية علي معلومات وممارسات الممرضات و انعكاس ذلك علي رضا السيدات عن الفحوصات النسائية تم استخدم المنهج شبة التجريبي لعمل الدراسة علي (40)ممرضه و (120) سيده من المترددات علي مستشفيي الازهر الجامعي ومستشفيي الزرقا

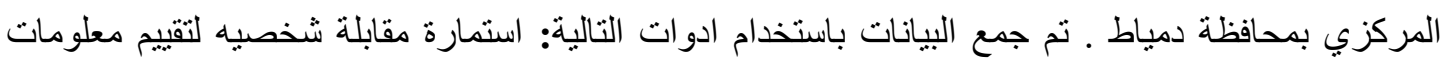
الممرضات عن الفحوصات النسائية ومقياس ملاحظة لأداء الممرضات قبل واثناء وبعد الفحوصات النسائية ومقياس لرضي السيدات عن مستوي الرعاية التمريضية بعيادات النساء، وقد استخلصت النتيجة ان ـ 87.5\% من الممرضات بعد تطبيق البرنامج اصبحت لديهم معلومات صحيحة و 85\% منهم لايهم ممارسات صحية مرضية 95\% من السيدات راضيات عن الخدمات التمريضية.وقد اظهرت نتائج الدراسة تحسن ايجابي احصائي ملحوظ في معلومات وممارسات الممرضات ورضا السيدات عن جودة الرعاية التمريضية بعد تطبيق الكتيب الارشادي واوصت الدر اسة بتقديم ارشادات تعلمية مستمرة للممرضات بخصوص الفحوصات النسائية . و اوصت الدراسة باستمر ار البحث في هذا الموضوع وخاصة الفحص الذاتي للمهيل لدي السيدات

الكلمات المرشدة : الفحوصات النسائية، المعلومات وممارسات التمريضية ،كتيب ارشادي تعليمي رضا

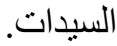

